\title{
Alteration of the Reproductive Patterns in Drosophila melanogaster by Effects of High Concentrations of Boron on In Vitro Cultured Medium
}

\author{
Alteración de los Patrones Reproductivos en Drosophila melanogaster por \\ Efectos de Altas Concentraciones de Boro en un Medio de Cultivo In Vitro
}

"Espinoza-Navarro, O.; ** Rodríguez, H.; "Rodríguez, M.; "Silva, E. \& "Luque, A.

ESPINOZA-NAVARRO, O.; RODRÍGUEZ, H.; RODRÍGUEZ, M.; SILVA, E. \& LUQUE, A. Alteration of the reproductive patterns in Drosophila melanogaster by effects of high concentrations of Boron on in vitro cultured medium. Int. J. Morphol., 27(3):765-770, 2009.

SUMMARY: The objective of this study was to evaluate the effects of boron (B) using as a biological model Drosophila malanogaster. Analizing specifically the responses over descendency to doses of 6,0 and $12 \mathrm{mg} / \mathrm{L}$, comparing a control group which culture medium was prepared with water with boron concentrations of $0,6 \mathrm{mg} / \mathrm{L}$, according to World Health Organization. The results show a significative alteration in the number of descendency from F1 to F3 and then a tendency to normalization in F4 and F5. Also a significant change in proportions between the males and females, with an acute effect on F1 and then a possible chronic effect from F2 to F5, increasing the proportion of females over males. This differences between genders are significant only until F4, on F5 these proportions are not significant. In F3 in doses of $12.0 \mathrm{mg} / \mathrm{L}$ of boron, it is observed a larger range of changes, altering the phenotypic expression, where the numbers of males which increase their size are significantly higher of those females who increase their size, $10 \%$ and $5,2 \%$ respectively. There is a tendency to normality in every pattern of study from the descendants of F4 and F5, above all the percentage of survival, possibly due action of steroid hormones of resistance to stress such as "ecdysone hormone".

KEY WORDS: Reproduction; Boron; Reproductive toxicology; Drosophila melanogaster.

\section{INTRODUCTION}

Because of the great advance of the contamination on the planet the necessity exists to establish protocols of investigation in environmental toxicology of fast execution, sensible and of little cost. Currently it has been proposed to use to Drosophila melanogaster like bio-sentinel for the environmental contamination, because they are easy to handle, inexpensive to maintain and their reproduction and growth well are documented besides its sequence and genetic mapping is currently well known (Adams et al., 2000; Hoskins et al., 2007).

In the last decade the city of Arica - Chile, has been affected by the serious problem of the contamination by boron in the drinking water. The normal concentration for boron in humans is reported to be 0.2 to $0.6 \mathrm{mg} / \mathrm{L}$ (Murray, 1995; Moore, 1997; Coughlin, 1998; WHO, 1998).
Nevertheless in the drinking water of Arica city these values are over the international parameters, because the water that is supplied to the city present rich geologic boron deposits, finally having variable levels that oscillate between 6.0 and $12 \mathrm{mg} / \mathrm{L}$ of boron. The boron (B) is an element widely distributed in the nature, in forms of borate and boric acid, in grounds, rocks and the oceans. The boron compounds are use in the glass industry, detergents, fertilizers, and herbicides. Boric acid and borate are completely absorbed orally and through exposed mucous.

Boron is reported to be a micro nutrient, essentials in several animal and vegetal species; with a low toxicity for humans. Nevertheless in higher doses it may affect the reproduction and development (Lanoue, 1998).

\footnotetext{
* Department of Biology, Faculty of Sciences, Universidad de Tarapacá, Chile.

** Laboratory of Biology of Reproduction ICBM Faculty of Medicine, Universidad de Chile.

Financing: Research Project $N^{\circ}$ 4705, Universidad de Tarapacá, Chile.
} 
The effects of high doses of boron have been studied in rats, mice and dogs, having an inhibition in the spermiation and focalized damage with increase of testicular size and weight, degeneration of seminiferous tubules, reduction of the spermatic count and therefore reduction of the fertility. Other effects of high doses in rabbits and mice involve reduction of the foetal weight and abnormalities in the skeleton (Price et al., 1996; Moorman et al., 2000; EspinozaNavarro et al., 2007).

Nevertheless there is no data available on professional exposition, accidental poisoning or epidemiologists' studies about the development of toxicity of boric acid in human (Sayli, 2003).

Huel (2004), affirms that in the Turkish populations in study there was an increase in the birth of girls, not related to random factors, but to the boron consumption, not being clear the reason of this behaviour.

The study of the morphologic and physiological changes in animal models, associated to the exhibition to contaminating agents and correlated to the genetic damage, allows to project the effects to the public health. These biological markers play an important role in the detection of the impact of the exposition and the prediction of risks in other populations. The problem of boron is normal in the few places where there are boron deposits, such as in Turkey, France, California and Chile, nevertheless the exposed population has the right to know the real effects of high concentrations of boron in public health (Luster et al., 1998; Spurgeon, 2004; Espinoza-Navarro). The present research study spefically will use as a biological model to Drosophila melanogaster to determine the effect of high concentrations of boron in their reproductive patterns.

\section{MATERIAL AND METHOD}

Drosophila melanogaster was obtained from Universidad de Chile. Flies were maintained in an environmentally controlled incubator at temperature of $25^{\circ} \mathrm{C}$, on $12 \mathrm{hr}$ light/ $12 \mathrm{hr}$ dark cycle at $70 \%$ relative humidity, with standardized nourishment prepared with Agar-Agar, yeast, sugar, banana, water and fungicide.

From these progenitors three groups were established (P1 = 5 females, 5 males), which food (culture medium) was prepared with the next types of water:

Control group: corresponds to individuals whose culture medium was prepared with distilled water with boron concentrations according to the norms established for human consumption by WHO and Claudio et al. (1999) establishing a range between 0.2 y $0.6 \mathrm{mg} / \mathrm{L}$.

Treated 1, which corresponds to insect grow in culture medium which have boron concentrations of $6.0 \mathrm{mg} / \mathrm{L}$.

Treated 2, developed in culture medium diluted in distilled water with concentrations of $12 \mathrm{mg} / \mathrm{L}$ for boron. ( $\mathrm{H}_{3} \mathrm{BO}_{3}, \mathrm{PM}$ : 61.83 purity 99.8, Scharlav).

This study does not consider a control group with total absence of boron, since the entire literature reported widely that this is an essential microelement, whose failure caused severe damage to the development and viability of the species.

For the recounts a stereoscopic 20X magnifier lens (Leitz Wetzlar 582533 Germany) was used, previously the flies were anesthetized with ether.

To efficiently determine the sex of the individuals were considered the parameters of sexual dimorphism, especially the presence of the male sex comb. Each work group was repeated 5 times. Eclosion periods of each stage of the life cycle of D. melanogaster were not considered in the study, however, the passage of a state of pupa to imago observed eclosion rates between $85 \%$ to $90 \%$ in all groups, and on each one of their offspring.

Euthanasia of individuals in the study was conducted according to accepted international protocols which were adopted by the Faculty of Medicine of Universidad de Chile.

The statistic test use to recount were the test " $\mathrm{t}$ " of student with a significance level of $p \leq 0.05$. It was also conducted an statistical " $\mathrm{z}$ " test to check the ratio between male and female

\section{RESULTS}

In Table I, show a percental difference between the ranges of survival among the treated groups in relation to the respective control groups on each generation. From F1 to F4 it is presented a significant diminishing of the percentage of survival with values of 71,6\% in F1 with doses of $12 \mathrm{mg} / \mathrm{L}$ of boron $(* * \mathrm{p} \leq 0.01)$ until $89.74 \%(* \mathrm{p} \leq 0.05)$ in $\mathrm{F} 4$ to equal doses.

In F5 it is observed higher levels of recuperation of 
survival of $93.5 \%$ and $91.3 \%$ at doses of 6.0 and $12.0 \mathrm{mg} / \mathrm{L}$ of boron respectively, which are not significant when comparing them with the individuals from the control group.

Table I. Shows the number of survival obtained in F1 to F5. It shows a significant diminution percentage of the insects in the groups treated with 6.0 and $12 \mathrm{mg} / \mathrm{L}$ of boron

\begin{tabular}{cccc}
\hline & \multicolumn{3}{c}{ Survival Percentage } \\
\hline Generation & \multicolumn{2}{c}{ Population (doses mg/L of boron) } \\
\hline F1 & Control & 6.0 & 12.0 \\
F2 & 100 & $72.84^{*}$ & $71.60^{* *}$ \\
F3 & 100 & $78.81^{* * *}$ & $70.18^{* * *}$ \\
F4 & 100 & $89.94^{*}$ & $86.88^{* *}$ \\
F5 & 100 & 94.02 & $89.74^{*}$ \\
\hline
\end{tabular}

$* \mathrm{p} \leq 0.05 ; * * \mathrm{p} \leq 0.01 ; * * * \mathrm{p} \leq 0.001$. In F5 there are no significant differences.

Table II show percent differences are observed regarding gender of the descendants. On F1 there is a significant increase of the male population over the female with a $54.5 \%$ and a $60.3 \%$ at doses of 6.0 and $12.0 \mathrm{mg} / \mathrm{L}$ of boron respectively $(* * * \mathrm{p} \leq 0.001)$. This situation overturns on F2 and F4 where the increase of percentage of females is significantly higher concerning males with values of $54.6 \%$ in $\mathrm{F} 2(* * * \mathrm{p} \leq 0.001)$ until $58.8 \%$ in $\mathrm{F} 4(* \mathrm{p} \leq 0.05)$ at doses of $12.0 \mathrm{mg} / \mathrm{L}$. On F5 there are no significant differences between the treated groups and the control groups.

Table II. Shows the percentage in genders acording to the treated groups. In F1 there is a significant increased of males over females

\begin{tabular}{|c|c|c|c|c|}
\hline \multirow{3}{*}{ Generation } & \multirow{3}{*}{ Gender } & \multicolumn{3}{|c|}{ Gender Percentage } \\
\hline & & \multicolumn{3}{|c|}{ Doses $\mathrm{mg} / \mathrm{L}$ of boron } \\
\hline & & Control & 6.0 & 12.0 \\
\hline \multirow[t]{2}{*}{ F1 } & Male & 48.3 & $54.5^{* * *}$ & $60.3 * * *$ \\
\hline & Female & 51.7 & 45.5 & 39.7 \\
\hline \multirow[t]{2}{*}{$\mathrm{F} 2$} & Male & 47.8 & 43.5 & 45.4 \\
\hline & Female & 52.2 & $56.5^{* * *}$ & $54.6 * * *$ \\
\hline \multirow[t]{2}{*}{ F3 } & Male & 48 & 44.5 & 46 \\
\hline & Female & 52 & $55.5^{*}$ & $54 *$ \\
\hline \multirow[t]{2}{*}{ F4 } & Male & 48.1 & 49.3 & 41.2 \\
\hline & Female & 51.9 & 50.7 & $58.8^{*}$ \\
\hline \multirow[t]{2}{*}{ F5 } & Male & 48.8 & 48.7 & 46.6 \\
\hline & Female & 51.2 & 51.3 & 53.4 \\
\hline
\end{tabular}

$* * * \mathrm{p} \leq 0.0010$, and from $\mathrm{F} 2$ to $\mathrm{F} 4$ there is a significant increase in females over males $* \mathrm{p} \leq 0.05 ; * * * \mathrm{p} \leq 0.001$. In F5 there are no significant differences.

In Figure 1, we shows the changes in sizes of the individuals in generation F3; treated with concentrations of $12 \mathrm{mg} / \mathrm{L}$ of boron. Females which maintain their size nor- mal were an $89 \%$ and males with an $86.2 \%(2.5 \mathrm{~cm}$ and 2.0 $\mathrm{cm}$ respectively). The percentage of male and females which diminish their size (5.8\% and 3.8\%) show no significant difference among them. Nevertheless, the percentage of males who increase their size $(10 \%)$ is significant higher over the percentage of females which increase their size with a $5.2 \%(* \mathrm{p} \leq 0.05)$.

The changes in size of the individuals are observed only in $\mathrm{F} 3$ population treated with $12.0 \mathrm{mg} / \mathrm{L}$ of boron. On the other groups these changes were not observed. In the control groups of all generation the percentages in gender are constantly maintain with values of $48 \%$ for males and $52 \%$ for females.

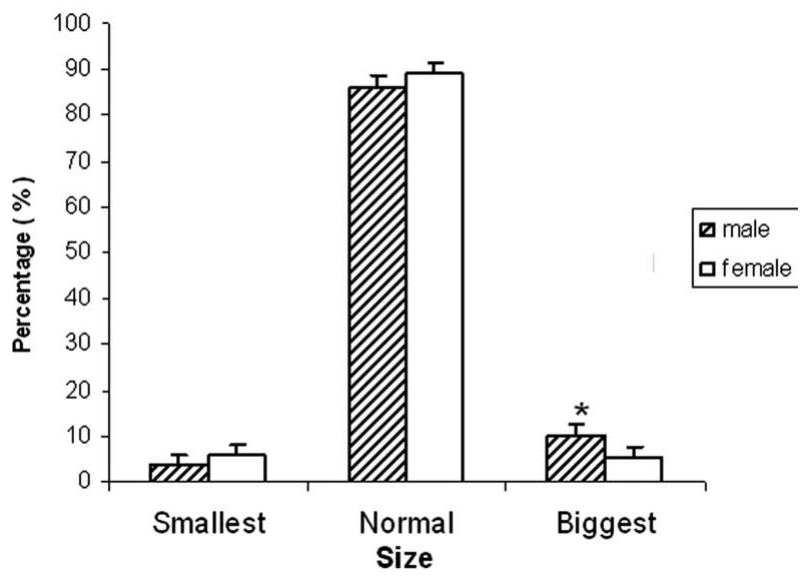

Fig. 1. It is observed a change in generation F3 at doses of 12,0 $\mathrm{mg} / \mathrm{L}$ of boron, were the percentage of males who increase their size is signicat higher over the females who increase their size from $10 \%$ and $5.2 \%$ respectively $(* \mathrm{p} \leq 0.05)$.

\section{DISCUSSION}

The results allow establishing that the boron has a deep effect in the number of individuals of the descendants. Table I also show that in the first offspring (F1), the percentage of males with high concentrations of boron $(6.0$ and $12.0 \mathrm{mg} / \mathrm{L})$ is significantly higher than females $(\mathrm{p} \leq 0.001)$. However, in F2 to F4 significantly change the proportions expressing a significant increase in females compared to males in the groups that are treated with high concentrations of boron ( $\mathrm{p} \leq 0.05$ and 0.001 respectively).

A $10 \%$ of the population of males descendants of F3, treated at doses of $12 \mathrm{mg} / \mathrm{L}$ of boron, show a significant increase in body size $(\mathrm{p} \leq 0.05)$. These results could express an acute answer in F1 and a chronic answer in F2 to F4 (Massie et al., 1990; Massie, 1994). 
The changes in higher concentrations of boron in Drosophila melanogaster could be due to the mechanism that determines the gender which differs from the mammals. In Drosophila melanogaster the number of chromosomes X determines the gender. $X X$ produce a female, $X$ produce a male, which means that XXY produce a female. Observations show that flies that haven't the gene DSX (double sex) have masculine and feminine features and this would be indicating a genetic inactivity that leads to mutations (Baker, 1989; Nurminsky et al., 2001; Griffiths et al., 2002).

Changes in the number and size of individuals can alter reproductive processes in mating and development. Dukas (2005), determines the choice of the female preference for smaller males during courtship and Wong et al. (2008), identifies the importance of seminal fluid proteins from males (ACPs) in behavior and in the immunity of the females after mating. These authors argue that sexual selection can be the basis for the adaptation of species.

Christiansen et al. (2002) and Arbeitman et al. (2002), postulate that sexual dimorphism involves signaling molecules (FGF, TGF beta and Wnt) and transcription factors (BAB, DAC) which can be affected by other factors. The work in vivo and in vitro, by Benderdour et al. (1998) show a large impact of boron in both plant and animal cells, especially as a stabilizer of biological membranes, potentially altering the activity of $\mathrm{Na}+\mathrm{K}+$ pump and due this mechanism affecting the concentration of hormones and brain function. Currently Shirangi \& McKeown (2007), postulate that sexual differentiation results of multiple genetic and nervous interactions.

These observations have a direct relation with the results presented and allow inferring that the sustained action of boron has a deep effect in the descendants of subjects in both males and females, affecting the reproductive patterns which produce the phenotypic changes. The work done by Massie et al., have identified the importance of the concentrations of boron in each stage of the life cycle of $D$. melanogaster, found high concentrations in the egg stage, a decrease in the larval stage and then an increased again in adulthood. The boron supplement in the diet in the adult however showed that the lifespan of insects fell drastically from $69 \%$ at doses of $0.01 \mathrm{M}$ sodium borate and to $21 \%$ at concentrations of sodium borate $0.001 \mathrm{M}$. This clearly indicates that boron is essential throughout the process of development of Drosophila. Also Massie, found that when analyzing tissue of mice and humans young and old, there were similar concentrations of boron.

The levels of recovery observed on F4 and F5 could also have a direct relation to hormonal changes in the way that would affect the expression of hormone "Ecdysone" the major steroid hormone of D. melanogaster regulating reproduction and development, extend the life (life-span) and resistance to stress (Simon et al., 2003).

This study on the effect of high concentrations of boron in sub-lethal reproductive parameters may be the beginning of further investigations to establish clearly the real effects of boron, an element that is now reported as a micro element, but in high doses can significantly alter the patterns of development and reproduction. Some authors report that even boron supplements have a beneficial effect in the treatment of prostate cancer and the treatment of wounds (Barranco \& Eckhert, 2004; Nzietchueng et al., 2002). Gentz \& Grace (2006) even postulate that boron in high concentrations could be use as an excellent repelent against the attack of insects over lumber.

The effect of boron in high doses presents currently many questions in health, such is its important that for example Jensen (2008); Xing et al. (2008); and Robbins (2008), set better norms of safety for workers and population exposed to boron contamination. Regarding the levels of boron in drinking water for the human population, as long as there are no detailed studies about boron, it is fundamental to follow the suggested norms by World Health Organization which sets the accepted levels of this element form 0.2 to $0.6 \mathrm{mg} / \mathrm{L}$.

\section{CONCLUSIONS}

The ingestion of boron through the water in preparation of culture medium for Drosophila melanogaster during their life cycle reduces significantly the survival percentage population (number of descendants) in generations F1, to F5. Boron alters the reproductive patterns of Drosophila melanogaster; altering the percentages of females and males in the descendants. In the third generation (F3), boron alters the number of individuals and alters the size of individuals (doses of $12.0 \mathrm{mg} / \mathrm{L}$ of boron), with a significant increase in males larger than normal (about 2.0 $\mathrm{cm})$.

This finding could have a huge role in courtship and mating behavior in D. melanogaster. The Boron acts directly on the sexual differentiation in $D$. melanogaster, possibly affecting the expression of the $\mathrm{X}$ chromosome, causing a cascade of events that would alter extremely the courtship and mating behavior in this species. The levels of recovery observed in F4 and F5; could be due the action of the hormone "ecdysone". 
Finally it is conclude that Drosophila melanogaster is an appropiate model of bio sentinel species capable to monitor the effects of boron in long and short time, at the sub lethal parameters of reproduction. These obtained results on bio-sentinel species could be taken as referents about the effects of boron in human population and establish over scientific bases a better management of drinking water with high levels of boron.

ACKNOWLEDGMENTS. The work was financed by Universidad de Tarapacá (Arica-Chile) Research Project UTA: $\mathrm{N}^{\circ} 4705$.

ESPINOZA-NAVARRO, O.; RODRÍGUEZ, H.; RODRÍGUEZ, M.; SILVA, E. \& LUQUE, A. Alteración de los patrones reproductivos en Drosoiphila melanogaster por efectos de altas concentraciones de Boro en un medio de cultivo in vitro. Int. J. Morphol., 27(3):765770, 2009.

RESUMEN: El objetivo de este estudio fue evaluar el efecto del boro (B), usando como modelo biológico a Drosophila melanogaster. Específicamente analizar las respuestas sobre la descendencia a dosis de 6,0 y $12 \mathrm{mg} / \mathrm{L}$ y comparar con el grupo control cuya concentración de boro en el agua del medio de cultivo no supera los 0,6 mg/L, según los estándares de la Organización Mundial de la Salud. Los resultados muestran una alteración significativa en el número de la descendencia desde F1 a F3 y luego una tendencia a la normalización a partir de la F4 y F5. También hay un cambio significativo en las proporciones entre machos y hembras, con un efecto agudo en F1 y luego un posible efecto crónico desde F2 a F5, aumentando la proporción de hembras con respecto a los machos. Sin embargo estas diferencias entre sexos ya no son significativas solamente hasta F4. En F5 estas proporciones no son significativas. En F3 en dosis de $12 \mathrm{mg} / \mathrm{L}$ de boro, se observan los mayores cambios, alterando la expresión fenotípica, donde el número de machos que incrementan su tamaño, son significativamente más altos con respecto a las hembras que aumentan de tamaño. La tendencia a la normalidad en todos los patrones de estudio a partir de la descendencia F4 a F5, sobre todo en el porcentaje de sobreviva, posiblemente se deba a la acción de hormonas esteroidales de resistencia al estrés, tal como la hormona "Ecdysona".

\section{PALABRAS CLAVE: Reproducción; Boro; Toxicología reproductiva; Drosophila melanogaster.}

\section{REFERENCES}

Adams, M. D.; Celniker, S. E.; Holt, R. A.; Evans, C. A.; Gocayne, J.D.; Amanatides, P.G., et al. The genome sequence of Drosophila melanogaster. Science, 287:2185-95, 2000.

Arbeitman, M.; Furlong, E.; Iman, F.; Johnson, E.; Null, B.; Baker, B.; Krasnow, M.; Scott, M.; Davis, R. \& White, K. Gene expression during the life cycle of Drosophila melanogaster. Science, 297(5590):2270-5, 2002.

Baker, B. S. Sex in flies: the splice of life. Nature, 340:5214, 1989.

Barranco, T. \& Eckhert, C. Boric acid inhibits human prostate cancer cell proliferation. Cancer Lett., 216(1):21-9, 2004.

Benderdour, M.; Bui-Van, T.; Dicko, A. \& Belleville, F. In vivo and in vitro effects of boron and boronated compounds. J. Trace Elem. Med. Biol., 12(1):2-7, 1998.

Christiansen, A.; Keisman, E.; Ahmad, S. \& Baker, B. Sex come in from the cold: the integration of sex and pattern. Trends Genet., 18(10):510-6, 2002.

Coughlin, J. R. Sources of human exposure: oreview of water supplies as sources of boron. Bio. Trace Elem. Res., 66(13):87-100, 1998.
Dukas, R. Learning affects mate choice in female fruit flies. Behav. Ecol., 16(4):800-4, 2005.

Claudio, L.; Bearer, C. F. \& Wallinga, D. Assessment of the U.S. Environmental Protection Agency methods for identification of hazards to developing organisms, Part I: The reproduction and fertility testing guidelines. $A m$. J. Ind. Med., 35(6):543-53, 1999. (APA)

Espinoza-Navarro, O.; Vilaxa, A.; Granifo, L.; Rojas, S. \& Rodríguez, H. Histological study on the male reproductive organs of Mouse CF1, treated with boron. Int. J. Morphol.; 25(2):341-46, 2007.

Gentz, M. C. \& Grace, J. K. A Review of Boron Toxicity in Insects with an Emphasis on Termites. J. Agr. Urban Entomol., 23(4):201-7, 2006.

Griffiths, A.; Miller, J. H.; Suzuki, D. T.; Lewontin, R. C. \& Gelbart, W. M. An introduction to genetic analysis. $7^{\circ}$ Ed. New York, W. H. Freeman \& Co., 2002.

Hoskins, R.; Carlson, J.; Kennedy, C.; Acevedo, D.; Evans-Holm, M.; Frise, E.; Wan, K. H.; Park, S.; Mendez-Lago, M.; Rossi, F.; Villasante, A.; Dimitri, P.; Karpen, G. H. \& Celniker, S. E. Sequence finishing and mapping of Drosophila melanogaster heterochromatin. Science, 316(5831):1625-8, 2007. 
ESPINOZA-NAVARRO, O.; RODRÍGUEZ, H.; RODRÍGUEZ, M.; SILVA, E. \& LUQUE, A. Alteration of the reproductive patterns in Drosophila melanogaster by effects of high concentrations of Boron on in vitro cultured medium. Int. J. Morphol., 27(3):765-770, 2009.

Huel, G.; Yazbeck, C.; Burnel, D.; Missy, P. \& Kloppmann, W. Environmental boron exposure and activity of deltaaminolevulinic acid dehydratase (ALA-D) in a newborn population. Toxicol. Sci., 80(2):304-9, 2004.

Jensen, A. A. Risk assessment of boron in glass wool insulation. Environ. Sci. Pollut. Res. Int., 16(1):73-8, 2008 .

Lanoue, L.; Taubeneck, M. W.; Muniz, J.; Hanna, L. A.; Strong, P. L.; Murray, F. J.; Nielsen, F. H.; Hunt, C. D. \& Keen, C. L. Assessing the effets of low boron diets on embryonic and fetal development in rodents using in vitro and in vivo model systems. Biol. Trace Elem. Res., 66(13):271-98, 1998.

Luster, M.; Munson, A.; Thomas, P.; Holsapple, M.; Fenters, J.; White, K.; Laver, L.; Gemolec, D.; Rosenthal, G. \& Dean, J. Development of a testing battery to assess chemical-induced immunotoxicity: National toxicology program's guidelines for immunotoxicity evaluation in mice. Fundam. Appl. Toxicol., 10(1):2-19, 1988.

Massie, H.R.; Whitney, S. J.; Aiello, V. R. \& Sternick, S. M. Changes in boron concentration during development and ageing of Drosophila and effects of dietary boron on life span. Mech. Ageing Dev., 53(1):1-7, 1990.

Massie, H. R. Effects of dietary boron on the ageing process. Environ. Health Persp., 102(7):45-8, 1994.

Moore, J. A. An assessment of boric acid and boron using the IEHR evaluative process for assessing Human Developmental and Reproductive Toxicity of Agents. Expert Scientific Committee. Reprod. Toxicol., 11(1):123-60, 1997.

Moorman, W. J.; Ahlers, H. W.; Chapin, R. E.; Daston, G. P.; Foster, P. M., Kavlock, R. J.; Morawetz, J. S.; Schnorr, T. M. \& Schrader, S. M. Prioritization of NTP reproductive toxicants for field studies. Reprod. Toxicol., 14(4):293-301, 2000.

Murray, F. J. A human health risk assessment of boron (boric acid and boron) in drinking water. Regul. Toxicol. Pharmacol., 22(2):221-30, 1995.

Nurminsky, D.; De Aguiar, D.; Bustamante, C. \& Hartl, D. Chromosomal effects of rapid gene evolution in Drosophila melanogaster. Science, 291(5501):128-30, 2001.

Nzietchueng, R. M.; Dousset, B.; Franck, P.; Benderdour,
M.; Nabet, P. \& Hess, K. Mechanisms implicated in the effects of boro non wound healing. J. Trace Elem. Med. Biol., 16(4):239-44, 2002.

Price, C.; Strong, P.; Marr, M., Myers, C. \& Murray, F. Developmental toxicity NOAEL and postnatal recovery in rats fed boric during gestation. Fundam. Appl. Toxicol., 32:179- 93, 1996.

Sayli, B. S. Low frecuency of infertility among workers in a borate processing facility. Biol. Trace Elem. Res., 93(13):19-30, 2003.

Shirangi, T. \& McKeown, M. Sex in flies: What "body-mind" dichotomy? Dev. Biol., 306:10-9, 2007.

Simon, A.; Shih, C.; Mack, A. \& Benzer, S. Steroid control of longevity in Drosophila melanogaster. Science, 299(5611):1407-10, 2003.

Spurgeon, D.; Weeks, J. \& Van Gestel, C. A summary of eleven years progress in earthworm ecotoxicology. Pedobiología, 47(5-6):588-606, 2004.

Wong, A.; Turchin, M.; Wolfner, M. \& Aquadro, C. Evidence for positive selection on Drosophila melanogaster seminal fluid protease homologs. Mol. Biol. Evol., 25(3):497-506, 2008.

World Health Organizatio (WHO). Guidelines for drinkingwater quality. Health Criteria and others Supporting information, 2. 2nd Ed. Geneva, World Health Organization, 1998. pp.1-125.

Correspondence to:

Prof. Dr. Omar Espinoza-Navarro.

Laboratory of Biology of Reproduction and Development.

Universidad de Tarapacá

Casilla 7/D

Velásquez 1775

Arica - CHILE

Telephone: 5658205415.

Fax: 5658205484.

Email: oespinoz@uta.cl

Received: 28-05-2009

Accepted: 25-06-2009 